\title{
A review of the Effect of Calcination Temperature on the Properties of Calcined Clay Concrete
}

\author{
Mini Review \\ Volume 2 Issue 3- 2021
}

\begin{abstract}
Author Details
Kwabena Boakye ${ }^{1}$, Morteza Khorami ${ }^{1 *}$, Eshmaiel Ganjian ${ }^{2}$, Messaoud Saidani ${ }^{1}$

${ }^{1}$ Faculty of Engineering, Environment \& Computing Coventry University, UK

${ }^{2}$ Concrete Corrosion Tech Ltd., United Kingdom

*Corresponding author
\end{abstract}

Morteza Khorami, Institute for Future Transport and Cities (FTC), Faculty of Engineering, Environment \& Computing Coventry University, UK

Article History

Received: June 10, 2021 Accepted: June 30, 2021 Published: July 02, 2021

\begin{abstract}
Naturally occurring clays can produce an amorphous siliceous material possessing pozzolanic properties if is heated at an appropriate temperature. Calcination at the right temperature is crucial since it affects the formation of relevant phases, pozzolanic reactivity, hydration kinetics and consequently, increase the strength and durability of concrete. This paper reviews the effect of calcination temperature on the properties of mortar and concrete corporating calcined clay as partial cement replacement. It is observed that calcination temperatures close to $900^{\circ} \mathrm{C}$ decrease the specific surface and represent the onset for the structural reorganization of aluminosilicates. Both factors limit the pozzolanic reactivity and can consequently compromise compressive strength. The results show that mortar containing $20 \%$ calcined clay obtained compressive strength of $63 \mathrm{MPa}$ when calcined at $800 \mathrm{oC}$, surpassing the reference cement by about $8 \mathrm{MPa}$.
\end{abstract}

Keywords: Pozzolanic reactivity; Calcination temperature; Aluminosilicates; Calcined clay; Compressive strength

\section{Introduction}

Due to the increasing concerns over the global emissions of $\mathrm{CO}_{2}$ by the cement industry, supplementary cementitious materials ( $\mathrm{SCMs}$ ) after decades of research have been proposed to partially replace the clinker component in cement without compromising its technical properties. Examples of such supplementary cementitious materials are pulverized fly ash obtained from coal-fired power plants, silica fume obtained as a by-product from the production of elemental silica, calcined clays obtained from the burning of natural clays, Ground Granulated Blast Furnace Slag (GGBS) obtained as a by-product of steel production, and rice husk ash, also obtained as agricultural waste, etc. These materials have been known to improve concrete properties such as compressive strength, durability and impermeability through hydraulic or pozzolanic activity [1].

Among the known SCMs, the most commonly utilized is fly ash which is produced from coal power plants [2]. However, recent concerns over fly ash availability have necessitated the exploration of other materials that could be used in its place [3]. Another known suggestion is the utilization of naturally occurring clays, which when is heated at an appropriate temperature, produces an amorphous siliceous material possessing pozzolanic properties. This possibility of processing clays into pozzolans is particularly viable since there are large clay deposits worldwide. Calcined clays are considered as pozzolanic materials due to their siliceous and/or siliceous aluminous nature and ability to chemically react with calcium hydroxide $(\mathrm{CH})$ in presence of moisture at ordinary temperatures to form compounds possessing cementitious properties [4].

Over the years, researchers have investigated several properties of calcined clay. This paper aims to review the effect of calcination temperature on the properties of calcined clay in mortar and concrete applications.

\section{Calcination Temperature}

Thermal treatment involves heating the clay mineral to a predetermined temperature, causing the octahedral layer to undergo dihydroxylation in a process known as calcination. The dehydroxylation results in a reduction in the bonding coordination number of the $\mathrm{Al}$ atoms in the octahedral sheet, making them more reactive. The exact nature 
of the structural transformation depends on many factors, including heating rate, holding temperature and time, atmosphere (oxidizing or reducing) and cooling rate [5-7].

Calcination at the right temperature is crucial since it affects the formation of relevant phases, pozzolanic reactivity, hydration kinetics and consequently, strength and durability of concrete. The temperature range for successful calcination of a given clay mineral must be high enough to achieve dehydroxylation, but not so high that recrystallisation occurs $[8,9]$.

Nawel et al. [10] studied the effect of temperatures $\left(600-800^{\circ} \mathrm{C}\right)$ on pozzolanic reactivity of Tunisian clays in terms of their physical, microstructural and mechanical properties. It was observed that pozzolanic reactivity was at its peak when the clay was calcined at $600^{\circ} \mathrm{C}$. Zhou et al. [11] investigated the influence of calcination temperature on excavated waste London clay. Kaolinite, illite and montmorillonite were found in clay that was calcined at $600^{\circ} \mathrm{C}, 700^{\circ} \mathrm{C}$, $800^{\circ} \mathrm{C}, 900^{\circ} \mathrm{C}$ and $1000^{\circ} \mathrm{C}$ for two hours. The kaolinite dehydroxylation happened between $350^{\circ} \mathrm{C}$ and $600^{\circ} \mathrm{C}$, while the montmorillonite and illite dehydroxylation took place between $600^{\circ} \mathrm{C}$ and $950^{\circ} \mathrm{C}$.

The pozzolanic activity was evaluated using the Frattini test, calcium hydroxide consumption test and strength activity index (SAI). According to Frattini test results, the calcined excavated waste clays at $800^{\circ} \mathrm{C}, 900^{\circ} \mathrm{C}$ and $1000^{\circ} \mathrm{C}$ showed activity after 8 and 15 days of curing, as well as higher percentages of consumption of calcium hydroxide. The SAI at 28 days was greater than 0.75 for calcined clays between $700^{\circ} \mathrm{C}$ and $1000^{\circ} \mathrm{C}$. Overall, Zhou et al. [11] settled on $900^{\circ} \mathrm{C}$ as the optimum calcination temperature for the best reactivity and the result of XRD is shown in Figure 1.

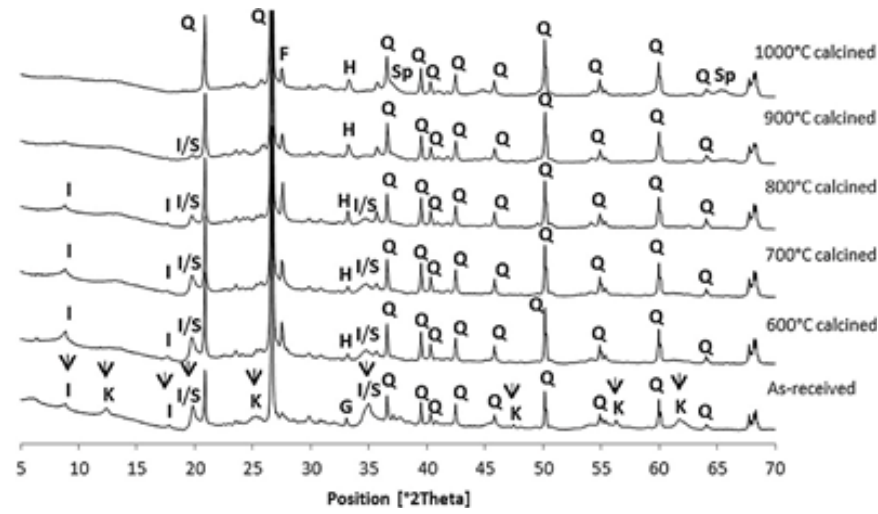

Figure 1: XRD data of as-received London clay and London clay calcined at different temperatures (K: Kaolinite; I: Illite; S: Smectite; Q: Quartz; F: Feldspar; H: Hematite; G: Goethite; Sp: Spinel) [11].

Some other researchers [12-15], on the contrary, have calcined clays at lower temperature and yet obtained similar results. Alujas et al. [12] reported that calcination temperatures close to $900^{\circ} \mathrm{C}$ decrease the specific surface and represent the onset for the structural reorganization of aluminosilicates, both factors that limit the pozzolanic reactivity and can consequently compromise compressive strength.

Du and Pang [16] on the other hand investigated the pozzolanic activity of marine clay after thermal activation. The marine clay had a kaolinite content of approximately $20 \%$ and was calcined at $600^{\circ} \mathrm{C}$ $700^{\circ} \mathrm{C}$ and $800^{\circ} \mathrm{C}$. The pozzolanic reaction for calcined marine clay was evaluated through the cumulative heat released, calcium hydroxide consumption and compressive strength of mortar. Despite the low kaolinite content, mortar with marine clay calcined at $600^{\circ} \mathrm{C}$ exhibited a high strength activity index of approximately 0.9 .

Figure 2 shows the microstructures of marine clay without calcination and after $800^{\circ} \mathrm{C}$ calcination. Those large particles might be fine sand grains while the finer particles around them could be silt and fine clay particles. Figure $2 \mathrm{~b}$ shows very fine clay particles in the shape of irregular flakes. After calcination, the morphology did not alter for both the large and small particles, as displayed in Figure 2c \& 2d.
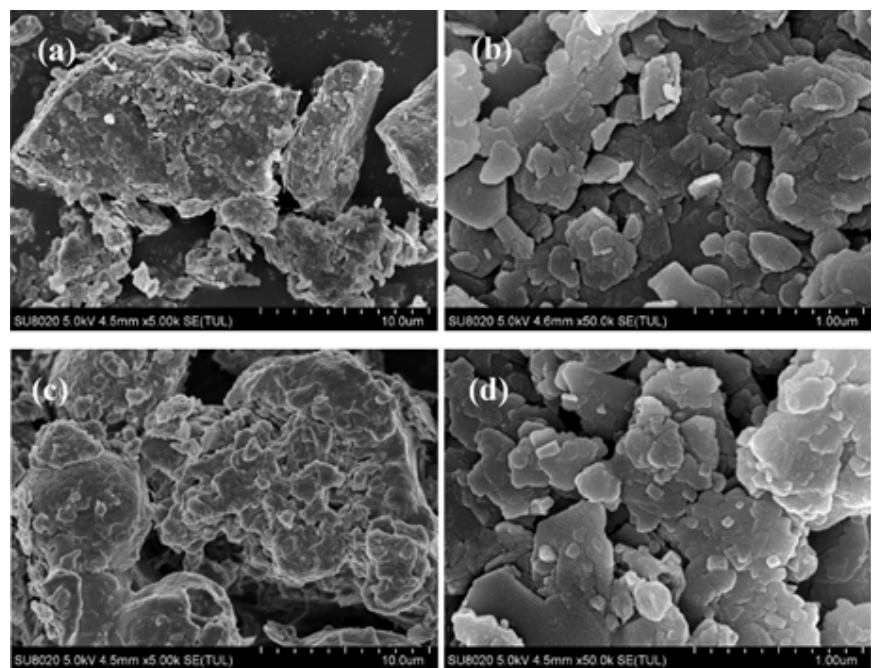

Figure 2: SEM images of Singapore marine clay (a) large particles and (b) small particles before calcination, (c) large particles and (d) small particles after $800^{\circ} \mathrm{C}$ calcination $[16]$

According to Ferreiro et al. [17], workability progressively improved with the increase of calcination temperature due to resulting lower specific surface area, as a consequence of increased clay transformation, which gave a spherical shape to some of the calcined clay particles. Strength performance was maximized for finely ground raw clays calcined at temperatures up to $850^{\circ} \mathrm{C}$. Ferreiro et al. [18] on the other hand studied two different clays and reported that Clay A seemed to be very reactive within the calcination temperature range between 700 and $800^{\circ} \mathrm{C}$. Within the whole temperature range, $20 \%$ replacement of cement with calcined Clay A resulted in compressive strength up to about $8 \mathrm{MPa}$ higher than what was achieved with the reference mortar. Calcined Clay B showed a narrower reactivity window. The reactivity can affect compressive strength development increasing from 700 to $800^{\circ} \mathrm{C}$ followed by a decrease from 800 to $1000^{\circ} \mathrm{C} .20 \%$ replacement of cement by Clay calcined at $800^{\circ} \mathrm{C}$ resulted in $7 \mathrm{MPa}$ higher 28-day compressive strength compared to the reference mortar as shown in Figure 3.
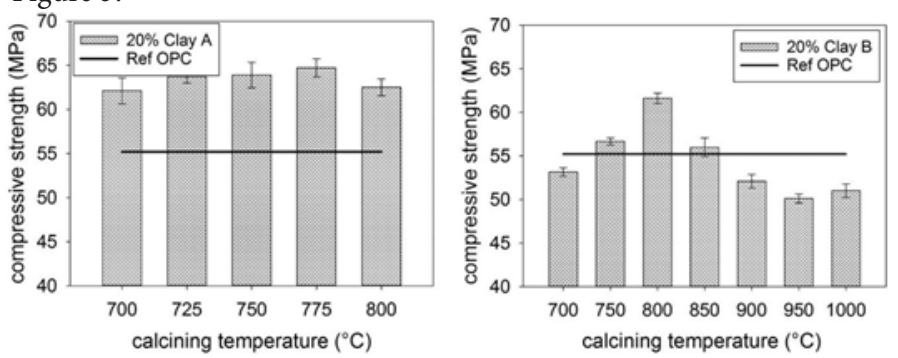

Figure 3: 28-day compressive strength of mortars with $20 \%$ replacement of cement by calcined Clay A (left) and calcined Clay B (right) [18].

\section{Conclusion}

The review conducted studies into the effect of calcination temperature on the properties of calcined clay for potential use as SCM in mortar and concrete applications. It is observed from this review that the pozzolanic reactivity of the calcined clay depends on the type and abundance of clay minerals in the raw material, the calcination temperature, method of calcination and the heating and cooling regime employed.

Complete dehydroxylation of kaolinite can be achieved between $600^{\circ} \mathrm{C}$ and $900^{\circ} \mathrm{C}$. Calcination temperature has the potential to affect properties of the calcined clay such as reactivity and compressive strength. Workability progressively improves with the increase of 
calcination temperature due to resulting lower specific surface area, as a consequence of increased clay transformation, which gives a spherical shape to some of the calcined clay particles. There could be about $8 \%$ increase in compressive strength when clays are calcined at temperatures between $700^{\circ} \mathrm{C}$ and $800^{\circ} \mathrm{C}$, all factors remaining constant.

\section{References}

1. Juenger MCG, Snellings R, Bernal SA (2019a) Supplementary Cementitious Materials: New Sources, Characterization, and Performance Insights. Cement and Concrete Research 122: 257-273.

2. El-Diadamony H, Amer AA, Sokkary TM, El-Hoseny S (2018) Hydration and characteristics of metakaolin pozzolanic cement pastes. HBRC Journal 14(2): 150-158.

3. Jaskulski R, Jozwiak-Niedzwiedzka D, Yakymechko Y (2020) Calcined clay as supplementary Cementitious material. Materials 13(21): 4734.

4. Amin N, Alam S, Gul S (2015) Assessment of pozzolanic activity of thermally activated clay and its impact on strength development in cement mortar. RSC Advances 5(8): 6079-6084.

5. Seiffarth T, Hohmann M, Posern K, Kaps C (2013) Effect of Thermal Pre-Treatment Conditions of Common Clays on the Performance of Clay-Based Geopolymeric Binders. Applied Clay Science 73: 35-41.

6. Tchadjie LN, Ekolu SO (2018) Enhancing the reactivity of aluminosilicate materials toward geopolymer synthesis. J Mater Sci 53: 4709-4733.

7. Khalifa AZ, Pontikes Y, Elsen J, Cizer Özlem (2019) Comparing the reactivity of different natural clays under thermal and alkali activation. RILEM Technical Letters 40: 74-80.

8. Heller-Kallai L (2013) Chapter 10.2 - Thermally Modified Clay Minerals. Developments in Clay Science 5: 411-433.

9. Snellings R, Mertens G, Elsen J (2012) Supplementary Cementitious Materials. Reviews in Mineralogy and Geochemistry 74 (1): 211-278.
10. Nawel S, Mounir L, Hedi H (2020) Effect of temperature on the pozzolanic reaction of Tunisian clays calcined in a laboratory. SN Applied Sciences 2: 157

11. Zhou D, Wang R, Tyrer M, Wong H, Cheeseman C (2017) 'Sustainable Infrastructure Development through the use of Calcined Excavated Waste Clay as a Supplementary Cementitious Material. Journal of Cleaner Production 168: 1180-1192.

12. Alujas A, Fernández R, Quintana R, Scrivener KL, Martirena F (2015) Pozzolanic Reactivity of Low-Grade Kaolinitic Clays: Influence of Calcination Temperature and Impact of Calcination Products on OPC Hydration. Applied Clay Science 108: 94-101.

13. Hollanders S, Adriaens R, Skibsted J, Cizer Ö, Elsen J (2016) Pozzolanic Reactivity of Pure Calcined Clays. Applied Clay Science 132(133): 552-560.

14. Fernandez R, Martirena F, Scrivener KL (2011) The Origin of the Pozzolanic Activity of Calcined Clay Minerals: A Comparison between Kaolinite, Illite and Montmorillonite. Cement and Concrete Research 41(1): 113-122.

15. Elimbi A, Tchakoute HK, Njopwouo D (2011) Effects of Calcination Temperature of Kaolinite Clays on the Properties of Geopolymer Cements. Construction and Building Materials 25(6): 2805-2812.

16. Du H, Pang SD (2018) Value-Added Utilization of Marine Clay as Cement Replacement for Sustainable Concrete Production. Journal of Cleaner Production 198: 867-873.

17. Ferreiro S, Herfort D, Damtoft JS (2017) Effect of Raw Clay Type, Fineness, Water-to-Cement Ratio and Fly Ash Addition on Workability and Strength Performance of Calcined Clay - Limestone Portland Cements. Cement and Concrete Research 101: 1-12.

18. Danner T, Norden G, Justnes H (2018) Characterisation of Calcined Raw Clays Suitable as Supplementary Cementitious Materials. Applied Clay Science 162: 391-402. 